\title{
Significant influence of self-possessed moisture of limonitic nickel laterite on sintering performance and its action mechanism
}

\author{
Yu-xiao Xue ${ }^{1} \cdot$ De-qing Zhu ${ }^{1} \cdot$ Jian Pan ${ }^{1} \cdot$ Zheng-qi Guo $^{1} \cdot$ Hong-yu Tian ${ }^{1} \cdot$ Gen $\mathrm{ij}^{1} \cdot$ Qing-zhou Huang $^{2} \cdot$ \\ Liao-ting $\operatorname{Pan}^{2} \cdot$ Xue-zhong Huang ${ }^{2}$
}

Received: 28 May 2021 / Revised: 27 July 2021 / Accepted: 7 August 2021 / Published online: 1 January 2022

(c) The Author(s) 2021

\begin{abstract}
In consideration of the abundant moisture of limonitic nickel laterite mined, it is essential to determine whether the selfpossessed moisture of limonitic nickel laterite after pre-dried is appropriate for sintering. Thus, based on the characterization of limonitic nickel laterite, the influence of its self-possessed moisture on sintering performance was expounded by sinter pot tests and the relevant mechanism was revealed by the systematical analyses of the granulation properties of sinter mixture, thermodynamic conditions during sintering and mineralogy of product sinter. The results indicate that the selfpossessed moisture of limonitic nickel laterite indeed has significant influence on its sintering performance. At the optimum self-possessed moisture of 21 mass $\%$, sinter indices are relatively better with tumble index, productivity and solid fuel rate of $48.87 \%, 1.04 \mathrm{t} \mathrm{m}^{-2} \mathrm{~h}^{-1}$ and $136.52 \mathrm{~kg} \mathrm{t}^{-1}$, respectively, due to the superior granulation properties of sinter mixture and thermodynamic conditions during sintering, relatively large amount of silico-ferrite of calcium and alumina and tighter sinter microstructure. However, sintering performance of limonitic nickel laterite is still much poorer than that of ordinary iron ores. It is feasible to strengthen limonitic nickel laterite sintering by inhibiting the over-fast sintering speed and improving the thermodynamic conditions during sintering.
\end{abstract}

Keywords Limonitic nickel laterite $\cdot$ Self-possessed moisture $\cdot$ Sintering performance $\cdot$ Action mechanism $\cdot$ Stainless steel

\section{Introduction}

Stainless steel industry is considered as the primary motivation for the growth of nickel production [1-3]. In China and the world, the percentages of nickel used for stainless steel production account for as high as $81 \%$ and $69 \%$ of the total nickel output in 2018, respectively. Correspondingly, the increasing demand for stainless steel worldwide leads to the gradual depletion of the more readily utilizable nickel sulfide resources $[4,5]$. Thus, the abundant nickel laterite resources accounting for about $70 \%$ of the total nickel resources have become the potential alternative

De-qing Zhu

dqzhu@csu.edu.cn

1 School of Minerals Processing and Bioengineering, Central South University, Changsha 410083, Hunan, China

2 Guangxi Beibu Gulf New Material Co., Ltd., Beihai 536000, Guangxi, China resources. Due to the severe shortage of nickel laterite resources, the external dependency of nickel laterite resources in China has exceeded $80 \%$ for many years. More notably, a significant part of the imported nickel laterite resources is identified as limonitic nickel laterite characterized by low nickel and high iron contents, owing to its rich reserves with about $60 \%$ share of the total lateritic nickel ore resources and the serious export restriction of high-quality nickel laterite resources overseas. It has been a key topic of how to achieve the effective utilization of limonitic nickel laterite for stainless steel production.

At present, rotary kiln-electric furnace and sinteringblast furnace processes are widely recognized as the main pyrometallurgical smelting processes of nickel laterite [6-8]. The former is intended for the production of ferronickel with 10-25 mass\% Ni by inhibiting iron reduction and improving nickel grade, which is suitable for nickel laterite with higher nickel and lower iron grades rather than 
limonitic nickel laterite. Comparatively, the effective utilization of limonitic nickel laterite can be commendably realized by producing stainless steel master alloy at lower cost through sintering-blast furnace process due to its relatively higher iron grade and lower price. Currently, a series of investigations on sintering tests of limonitic nickel laterite have been conducted and the relevant industrial applications have also been successfully carried out in Chinese stainless steel enterprises [9-12]. However, sintering performance of limonitic nickel laterite is characterized by poor tumble index $(<50 \%)$, low productivity $\left(<1.0 \mathrm{t} \mathrm{m}^{-2} \mathrm{~h}^{-1}\right)$ and high solid fuel rate $\left(>140 \mathrm{~kg} \mathrm{t}^{-1}\right)$ due to its high crystal water content ( $>15$ mass\%), low iron grade $(<50$ mass $\%)$ and extensive high melting minerals such as $\mathrm{Al}_{2} \mathrm{O}_{3}, \mathrm{MgO}$ and $\mathrm{Cr}_{2} \mathrm{O}_{3}$, which is much poorer than that of ordinary ores.

In general, limonitic nickel laterite mined always contains high percentage of water (>30 mass\%) due to the specific genesis of its deposits, which is too high to be directly used for sintering [13-15]. Thus, unlike the ordinary ore sintering, the pre-drying process of limonitic nickel laterite is essential for the proper dehydration before sinter proportioning process, commonly conducted in a drying kiln in practical production. In this paper, the moisture of limonitic nickel laterite after pre-dried is defined as its self-possessed moisture. Moreover, the external water is still requisite for the granulation process. As confirmed in the related studies [16-19], the initial water condition of iron ores has great effect on the granularity of sinter mixture and sintering process due to the different migration rates of water. If the self-possessed moisture of limonitic nickel laterite is not appropriate, it would not only result in the further worse sintering performance of limonitic nickel laterite, but also substantially increase the cost of the pre-drying process.

In this paper, according to the characterization of the used limonitic nickel laterite, sinter pot tests of limonitic nickel laterite were systematically carried out to reveal the significant influence of the self-possessed moisture of limonitic nickel laterite on its sintering performance. The relevant mechanism was clarified from the standpoints of the granulation properties of sinter mixture, thermodynamic conditions during sintering and mineralogy of product sinter. This study would provide good guidance for the practical production of limonitic nickel laterite and contribute to obtaining nickel-bearing sinter with better quality.

\section{Materials and methods}

\subsection{Characterization methods}

In this study, the characterization methods mainly include the determination of the chemical compositions and size distributions and the mineralogy analysis of raw materials and product sinter. The chemical compositions and size distributions were determined by means of X-ray fluorescence (XRF, Axios mAX XRF spectrometer, PANalytical B.V., Alemlo, Holland) analysis and a series of standard sieves $(0.15,0.25,0.5,1,3,5,6.3,8$ and $10 \mathrm{~mm})$ according to the standards of ISO 9516-1-2003 and ISO 4701-1999, respectively. The mineralogy analysis was conducted by means of X-ray diffraction (XRD), optical microscopy $(\mathrm{OM})$, scanning electron microscopy (SEM) and energy dispersive spectrometry (EDS). The XRD analysis was carried out by the aid of a Simens D500 automatic X-ray diffractometer (Siemens AG, Berlin, Germany) with copper target, which was operated at $40 \mathrm{kV}$ and $250 \mathrm{~mA}$ in step mode with $0.02^{\circ} 2 \theta$ step and a count time of $0.5 \mathrm{~s}$ per step over a $2 \theta$ range from $10^{\circ}$ to $80^{\circ}$. Subsequently, the software of MDI Jade 6.5 was used to analyze the XRD data. In addition, polished samples should be prepared before the micrographs shoot. Firstly, the samples were embedded by the acrylic powder and epoxy resin curing agent with the ratio of 1:1.8 in the relevant rubber mold and then made into cylindrical samples of $30 \mathrm{~mm}$ in diameter and $15 \mathrm{~mm}$ in height at room temperature. After polished by the semi-automatic grinding and polishing machine (Tegramin-25, Struers Ltd., Shanghai, China), the samples were placed in the optical microscope (Leica DM4500P, Leica Camera AG, Solms, Germany) by using reflected plane polarized light for the optical micrographs. According to the different colors of minerals and pores presented in the optical micrographs, the software of Image-Pro Plus 6.0 was adopted to quantitatively determine the mineral compositions and sinter porosity via the area calculation method. In each condition, about 50 sheets of optical micrographs with the magnification of $50 \times$ were shot evenly on the sinter samples for the measurement of sinter porosity, whereas about 200 sheets of optical micrographs with the magnification of $200 \times$ were obtained for the determination of mineral compositions in the same way, which can commendably ensure the accuracy and facticity of the statistical results on the conditions of covering all areas of the samples. The SEM-EDS analyses were completed by means of an environmental scanning electron microscope (ESEM, FEI Quanta-200, FEI, Hillsboro, OR, USA) equipped with an EDAX energy dispersive X-ray spectroscopy detector.

\subsection{Raw materials}

Table 1 presents the chemical compositions of raw materials, which are all supplied by Chinese steel enterprises. Limonitic nickel laterite imported from Philippines is identified as a refractory iron ore for sintering due to its rather lower iron grade of only 45.09 mass $\%$, higher LOI 
(loss on ignition) of 12.49 mass $\%$, and extensive gangue minerals, including 5.70 mass $\% \mathrm{SiO}_{2}, 4.50$ mass $\% \mathrm{Al}_{2} \mathrm{O}_{3}$ and 5.58 mass \% $\mathrm{MgO}$. Ferronickel tailing is a solid waste from the direct reduction-magnetic separation process of nickel laterite and adopted as a good alternative of the conventional sinter fluxes like serpentine because of the similar chemical compositions. Burnt lime contains 82.07 mass $\% \mathrm{CaO}$ and is used to adjust sinter basicity and improve granulation process. Anthracite possesses high fixed carbon content and calorific value of 79.66 mass\% and $28.27 \mathrm{MJ} \mathrm{kg}^{-1}$, respectively, and acts as the only solid fuel to provide sufficient heat for sintering process; the ash and volatile contents of the anthracite are 5.96 and 14.38 mass \%, respectively. Return fines are prepared uniformly for the stability of sintering process. The traces of hazardous elements containing $\mathrm{S}$ and $\mathrm{P}$ in all raw materials contribute to the reduction of production cost and improvement of stainless steel quality. As shown in Table 2, the particle of limonitic nickel laterite is relatively coarse with $+5 \mathrm{~mm}$ fraction of 16.16 mass $\%$, which is adverse to sinter consolidation. The $1-3 \mathrm{~mm}$ fraction is as high as 44.78 mass\%, promoting the improvement of the granulation process. The fluxes and solid fuel with over 70 mass $\%$ passing $3 \mathrm{~mm}$ and return fines with 100 mass\% passing $5 \mathrm{~mm}$ all meet the requirements of sinter production for the granularity.

Figure 1a indicates that limonitic nickel laterite mainly contains goethite $(\mathrm{FeO}(\mathrm{OH}))$ and a small amount of hematite $\left(\mathrm{Fe}_{2} \mathrm{O}_{3}\right)$, maghemite $\left(\mathrm{Fe}_{2} \mathrm{O}_{3}\right)$, enstatite $\left(\mathrm{MgSiO}_{3}\right)$ and stishovite $\left(\mathrm{SiO}_{2}\right)$. Figure $1 \mathrm{~b}$ illustrates that the granulation properties of limonitic nickel laterite are excellent due to its particles with various sizes, rough surfaces and loose textures. Combined with Fig. 1c, d and Tables 3 and 4, alumina in limonitic nickel laterite is mainly enriched in iron-bearing minerals including abundant earthy and vitreous goethite, a small amount of granular hematite, long strip maghemite and tabular Cr-spinel. Magnesium is predominantly associated with $\mathrm{Cr}$-spinel and enstatite whereas silicon primarily occurs in enstatite and stishovite. The distinctive element occurrence such as $\mathrm{Al}, \mathrm{Mg}$ and $\mathrm{Si}$ could have great influence on limonitic nickel laterite sintering.

\subsection{Experimental procedure}

Limonitic nickel laterite and anthracite acted as the only iron-bearing raw material and high-quality solid fuel respectively for sinter tests in a pilot scale pot with $200 \mathrm{~mm}$ in external diameter and $1000 \mathrm{~mm}$ in height (Fig. 2). According to previous investigations [9, 10, 20], the optimum sinter basicity should be maintained at 1.4 by adjusting the ratio of burnt lime whereas the proportions of return fines and ferronickel tailing were kept at 30 and 1.5 mass $\%$ on the basis of the total dry mix, respectively. In addition, limonitic nickel laterite samples with different self-possessed moisture $(17,19,21,23,25$ and 26 mass\%) were prepared by pre-drying. The detailed sinter pot test procedures were shown as follows, mainly including proportioning, mixing, granulation, ignition, sintering, cooling, crushing, dropping, sieving and quality testing of product sinter.

All raw materials in the required proportions were blended evenly with water and then loaded into a granulation drum with a diameter of $610 \mathrm{~mm}$ and length of $1000 \mathrm{~mm}$ for granulating at $25 \mathrm{r} \mathrm{min}^{-1}$ for $5 \mathrm{~min}$. The granulated product was defined as the green sinter mixture. The green sinter mixture was uniformly sampled to measure the moisture and $+3 \mathrm{~mm}$ fraction of sinter mixture. Subsequently, the adopted samples of the green sinter mixture were dropped from $1 \mathrm{~mm}$ at height for 10 times, and then, the $-0.5 \mathrm{~mm}$ fraction was determined for the characterization of drop strength of the green sinter mixture. The rest green sinter mixture was weighed and loaded into the sinter pilot scale pot. The thickness of hearth layer and the height of sinter bed were maintained at 10 and $700 \mathrm{~mm}$, respectively. The ignition of sinter mixture was conducted at $1100{ }^{\circ} \mathrm{C}$ and $6 \mathrm{kPa}$ for $1.5 \mathrm{~min}$. Sinter suction was kept at $10 \mathrm{kPa}$. During sintering, the exhaust-gas temperature of sinter bed was recorded as the evaluation index of the thermodynamic conditions of sintering process. The hot sinter cake was subjected to cooling for $5 \mathrm{~min}$ at $5 \mathrm{kPa}$ as the sintering process was finished. After cooling, sinter indices including vertical sintering speed, tumble index, productivity, yield and solid fuel rate were

Table 1 Chemical compositions of raw materials (mass\%)

\begin{tabular}{lrllrrrrrrr}
\hline Raw material & \multicolumn{1}{c}{$\mathrm{TFe}$} & $\mathrm{TNi}$ & $\mathrm{Cr}_{2} \mathrm{O}_{3}$ & \multicolumn{1}{c}{$\mathrm{SiO}_{2}$} & $\mathrm{CaO}$ & $\mathrm{Al}_{2} \mathrm{O}_{3}$ & $\mathrm{MgO}$ & $\mathrm{P}$ & $\mathrm{S}$ & $\mathrm{LOI}_{1000}{ }^{\circ} \mathrm{C}$ \\
\hline Limonitic nickel laterite & 45.09 & 0.86 & 3.45 & 5.70 & 0.12 & 4.50 & 5.58 & 0.001 & 0.011 & 12.49 \\
Ferronickel tailing & 5.82 & 0.51 & 0.86 & 44.08 & 1.04 & 1.34 & 31.98 & 0.001 & 0.005 & 6.84 \\
Burnt lime & 0.22 & - & - & 4.20 & 82.07 & 1.18 & 1.81 & 0.009 & 0.091 & 10.42 \\
Anthracite & 0.75 & - & - & 7.46 & 0.31 & 3.70 & 0.28 & 0.009 & 0.091 & 85.64 \\
Return fines & 48.06 & 0.72 & 2.51 & 6.58 & 9.21 & 5.48 & 1.98 & 0.001 & 0.006 & 0.00 \\
\hline
\end{tabular}

$\mathrm{LOI}_{1000}{ }^{\circ} \mathrm{C}$ Loss on ignition of dried samples at $1000{ }^{\circ} \mathrm{C}$ in air atmosphere 
Table 2 Size distributions of raw materials

\begin{tabular}{lcccccrrrrr}
\hline Size/mm & +10 & $8-10$ & $6.3-8$ & $5-6.3$ & $3-5$ & $1-3$ & $0.5-1$ & $0.25-0.5$ & $0.15-0.25$ & -0.15 \\
\hline Limonitic nickel laterite/mass\% & 2.80 & 3.30 & 4.06 & 6.00 & 22.35 & 44.78 & 6.43 & 5.83 & 1.17 & 3.28 \\
Ferronickel tailing/mass\% & 0.00 & 0.00 & 0.00 & 0.01 & 1.62 & 3.56 & 17.75 & 25.78 & 8.08 & 43.20 \\
Burnt lime/mass\% & 0.00 & 0.00 & 0.63 & 1.75 & 21.27 & 20.11 & 5.19 & 2.96 & 0.81 & 47.29 \\
Anthracite/mass\% & 1.68 & 1.58 & 1.70 & 3.70 & 18.08 & 15.23 & 15.46 & 14.10 & 5.22 & 23.25 \\
Return fines/mass\% & 0.00 & 0.00 & 0.00 & 0.00 & 42.11 & 26.75 & 13.27 & 8.36 & 6.64 & 2.87 \\
\hline
\end{tabular}
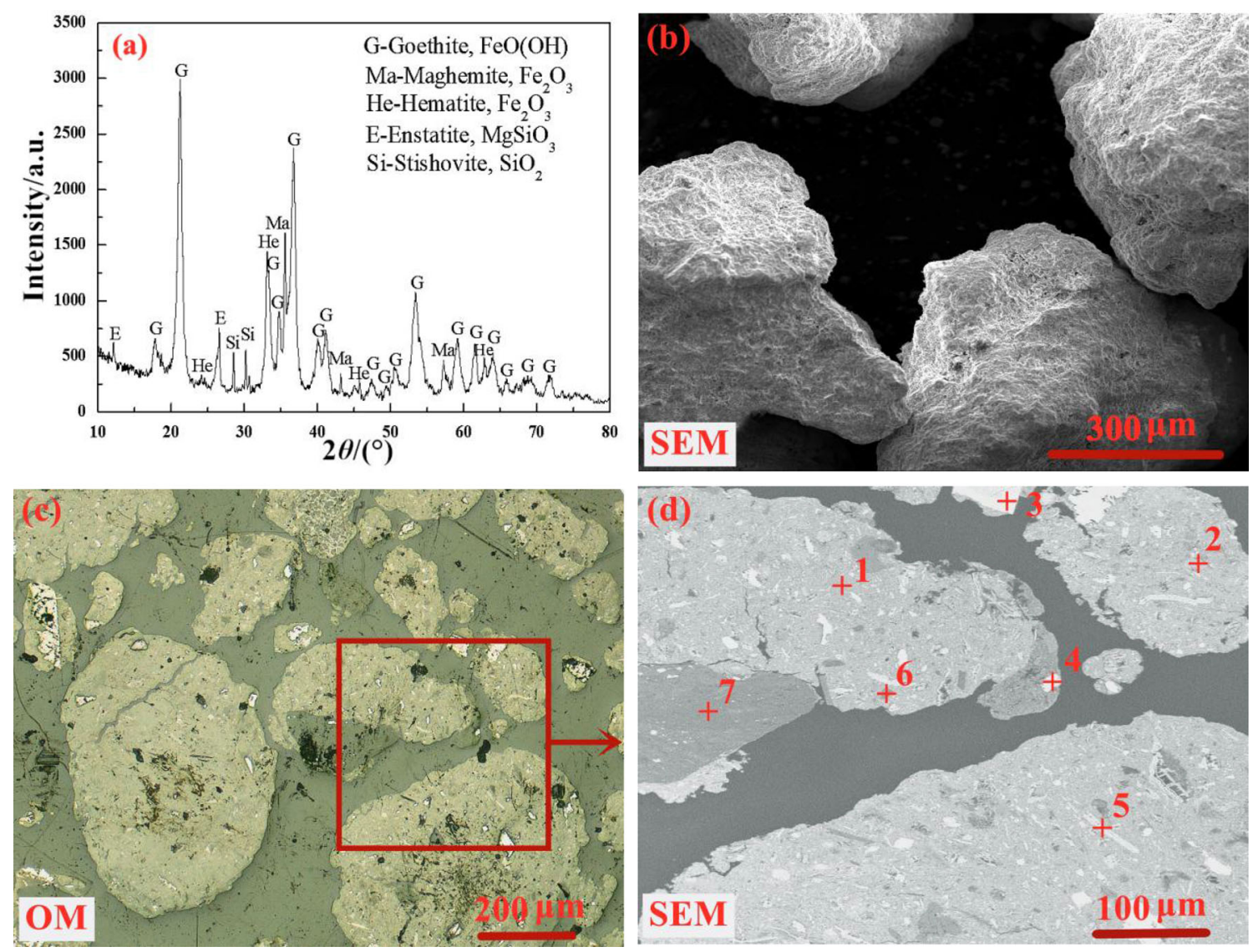

Fig. 1 Mineralogy of limonitic nickel laterite. a XRD patterns; b morphology image under SEM; $\mathbf{c}$ micrograph under OM; d micrograph under SEM

obtained, and the chemical compositions, metallurgical performance and the mineralogy of product sinter were determined. Generally, sinter yield was positively correlated with sinter productivity. Thus, sinter productivity was adopted to evaluate the output of product sinter in this paper. The relevant methods were exactly in accordance with the descriptions of previous studies [9, 10, 20]. Vertical sintering speed represented the average flame speed of sintering, which was described as the ratio of sinter bed height to sintering time. Tumble index was used to evaluate the strength of product sinter and identified as the mass ratio of $+6.3 \mathrm{~mm}$ fraction after tumbling to the total product sinter for tumbling according to the standard of ISO 3271-1995. Productivity reflected the output of product sinter and was defined as the ton output of product sinter every hour per square meter of sintering area. Solid fuel rate indicated the solid fuel consumption during sintering and was characterized as the kilogram dosage of solid fuel per ton of product sinter. Metallurgical performance included reduction index (RI) and reduction degradation index (RDI) and was determined referring to the standards of ISO 4696-2-1998 and ISO 4695-1995, respectively. The former was used to evaluate the reducibility of product sinter and defined as the deoxidation 
Table 3 EDS analysis results for areas in Fig. 1d

\begin{tabular}{|c|c|c|c|c|c|c|c|c|c|}
\hline \multirow[t]{2}{*}{ Area No. } & \multicolumn{8}{|c|}{ Elemental compositions/at.\% } & \multirow[t]{2}{*}{ Mineral phase } \\
\hline & $\mathrm{Fe}$ & $\mathrm{Cr}$ & $\mathrm{Ni}$ & $\mathrm{Mg}$ & $\mathrm{Al}$ & $\mathrm{Si}$ & $\mathrm{Ca}$ & $\mathrm{O}$ & \\
\hline 1 & 30.18 & 0.55 & 0.09 & 0.35 & 1.11 & 0.12 & 0.15 & 67.45 & Goethite $(\mathrm{FeO}(\mathrm{OH}))$ \\
\hline 2 & 32.68 & 0.67 & 0.13 & 0.51 & 1.34 & 0.25 & 0.19 & 64.23 & Goethite $(\mathrm{FeO}(\mathrm{OH}))$ \\
\hline 3 & 19.85 & 14.39 & - & 6.96 & 7.36 & 0.08 & 0.17 & 51.19 & Cr-spinel $\left((\mathrm{Fe}, \mathrm{Mg}) \cdot(\mathrm{Cr}, \mathrm{Fe}, \mathrm{Al})_{2} \mathrm{O}_{4}\right)$ \\
\hline 4 & 37.42 & 0.38 & 0.16 & 0.53 & 1.57 & 0.16 & 0.22 & 59.56 & Hematite $\left(\mathrm{Fe}_{2} \mathrm{O}_{3}\right)$ \\
\hline 5 & 35.19 & 0.46 & 0.18 & 0.49 & 1.35 & 0.24 & 0.18 & 61.91 & Maghemite $\left(\mathrm{Fe}_{2} \mathrm{O}_{3}\right)$ \\
\hline 6 & 0.16 & - & - & 0.07 & 0.11 & 35.36 & - & 64.30 & Stishovite $\left(\mathrm{SiO}_{2}\right)$ \\
\hline 7 & 0.58 & - & - & 17.39 & 0.32 & 18.76 & - & 62.95 & Enstatite $\left(\mathrm{MgSiO}_{3}\right)$ \\
\hline
\end{tabular}

Table 4 Detailed mineral compositions of limonitic nickel laterite in area fraction (\%)

\begin{tabular}{llllll}
\hline Goethite & Hematite & Maghemite & Enstatite & Stishovite & Cr-spinel \\
\hline 71.43 & 2.05 & 4.45 & 18.39 & 1.25 & 2.43 \\
\hline
\end{tabular}

degree during reducing for $3 \mathrm{~h}$ at $900{ }^{\circ} \mathrm{C}$ based on the trivalent iron state. The latter presented the strength of product sinter during low-temperature $\left(500{ }^{\circ} \mathrm{C}\right)$ reduction process, which was expressed as the mass ratios of +6.3 $\mathrm{mm},+3.15 \mathrm{~mm}$ and $-0.5 \mathrm{~mm}$ fractions of the reduced product sinter after tumbling, i.e., $\mathrm{RDI}_{+6.3 \mathrm{~mm}}, \mathrm{RDI}_{+3.15 \mathrm{~mm}}$ and $\mathrm{RDI}_{-0.5 \mathrm{~mm}}$, respectively. Moreover, the maximum molecular and capillary water contents of limonitic nickel laterite were tested for the comparison with those of ordinary iron ores according to the literatures [21-23].

\section{Results}

\subsection{Effect of self-possessed moisture on sinter indices}

With the optimization of sinter mixture moisture and anthracite dosage during sintering, the optimum sinter indices of limonitic nickel laterite are obtained when the return fines balance is achieved. When various amount of the external water was added, the optimum sinter mixture moisture would be different with the variation of the selfpossessed moisture of limonitic nickel laterite, further leading to the difference of the optimum anthracite dosage. Just as shown in Fig. 3, the optimum sinter mixture moisture is increased gradually with an increase in the selfpossessed moisture of limonitic nickel laterite. The optimum anthracite dosage is sharply reduced from 9.8 to 7.5 mass\% when the self-possessed moisture of limonitic nickel laterite rises from 17 to 21 mass\%. However, as the

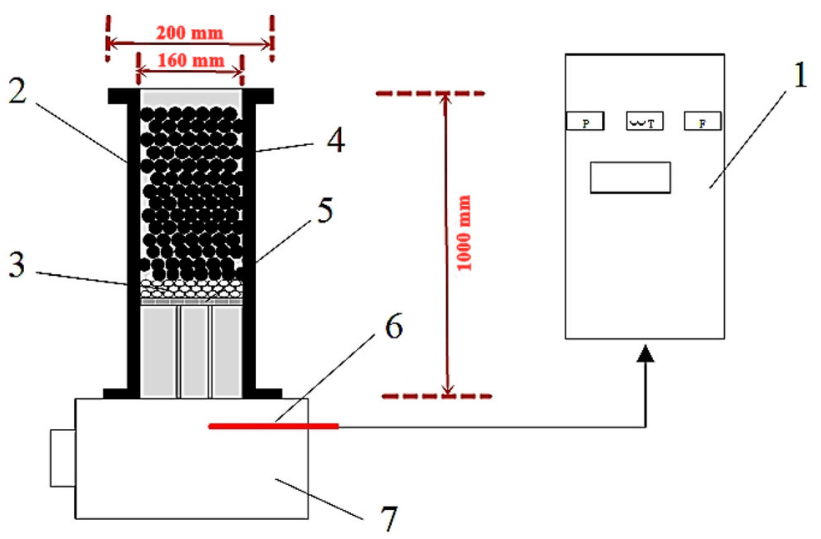

Fig. 2 Schematic diagram of used sinter pot. 1-Control cabinet; 2 sinter pot; 3-hearth layer; 4-sinter layer; 5-bar grate; 6thermocouple; 7-vacuum chamber

self-possessed moisture of limonitic nickel laterite reaches 26 mass \%, the optimum anthracite dosage is increased to $10.5 \mathrm{mass} \%$. The corresponding sinter indices of limonitic nickel laterite are presented in Fig. 4. As the self-possessed moisture of limonitic nickel laterite is elevated from 17 to 21 mass $\%$, tumble index and productivity of product sinter are obviously improved from $36.59 \%$ and $0.98 \mathrm{t} \mathrm{m}^{-2} \mathrm{~h}^{-1}$ to $48.87 \%$ and $1.04 \mathrm{t} \mathrm{m}^{-2} \mathrm{~h}^{-1}$, respectively, whereas solid fuel rate is greatly lowered from 160.75 to $136.52 \mathrm{~kg} \mathrm{t}^{-1}$. However, when the self-possessed moisture of limonitic nickel laterite further rises to 26 mass $\%$, sintering performance of limonitic nickel laterite is substantially deteriorated with tumble index and productivity reduced to $28.96 \%$ and $0.95 \mathrm{t} \mathrm{m}^{-2} \mathrm{~h}^{-1}$, respectively, and solid fuel 


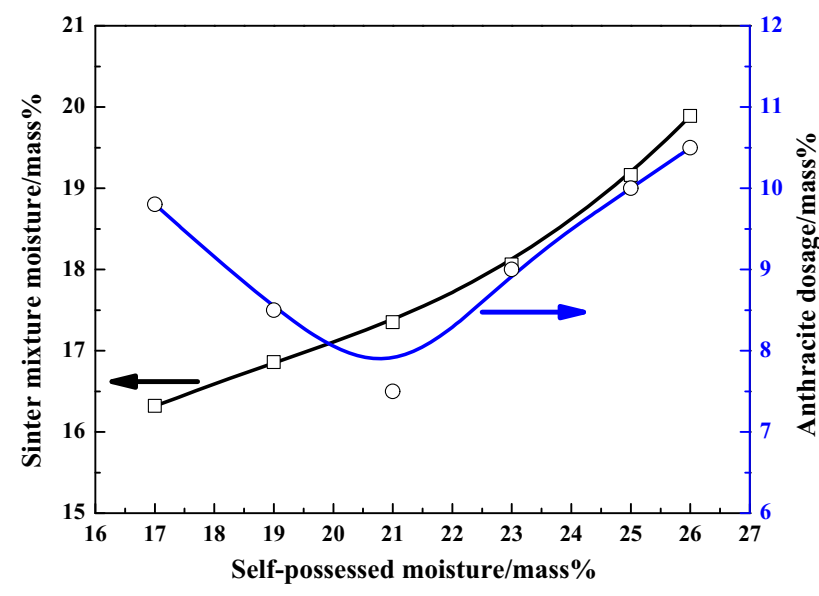

Fig. 3 Variation of optimum sinter mixture moisture and anthracite dosage with self-possessed moisture of limonitic nickel laterite

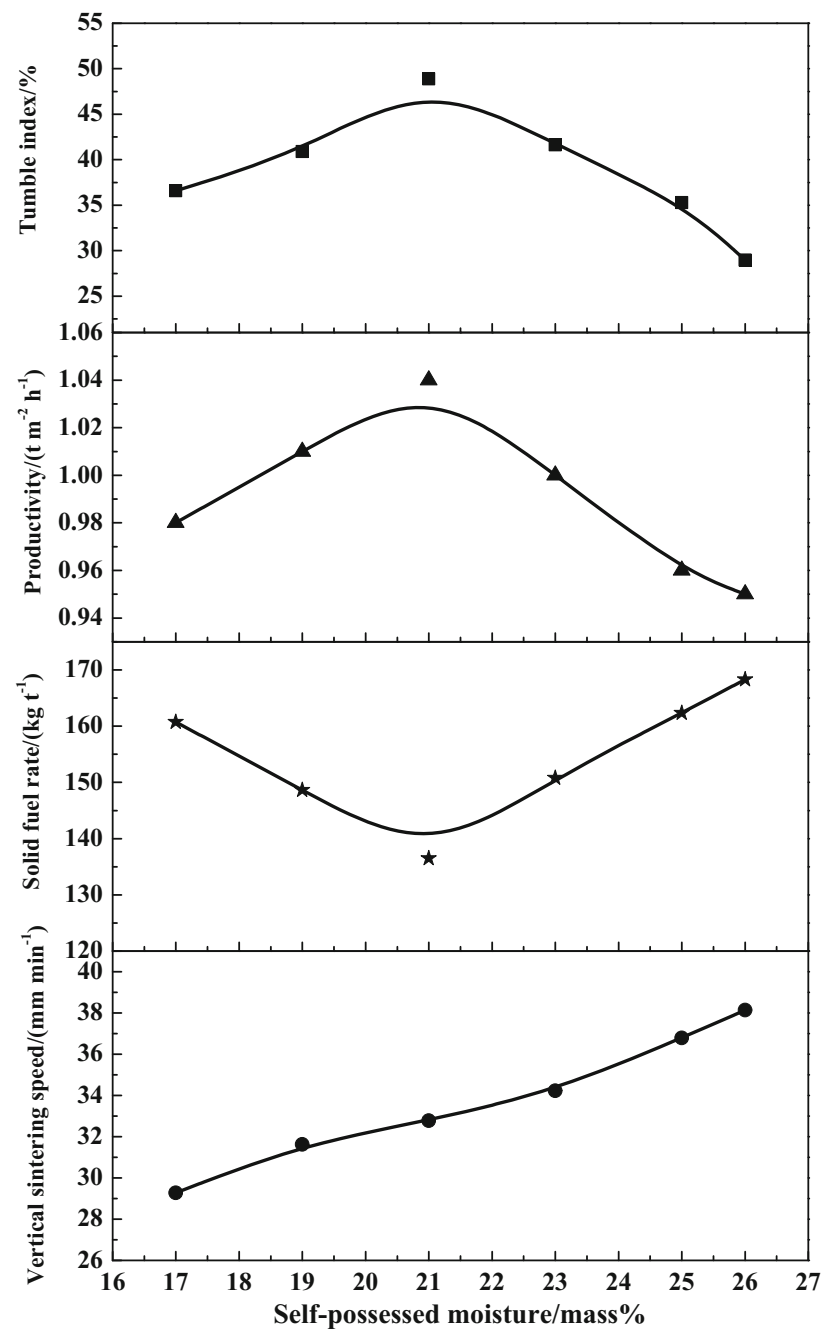

Fig. 4 Effect of self-possessed moisture of limonitic nickel laterite on sinter indices rate increased to $168.29 \mathrm{~kg} \mathrm{t}^{-1}$. Moreover, the vertical sintering speed is always increased with an increase in the self-possessed moisture of limonitic nickel laterite. It can be observed that higher or lower self-possessed moisture of limonitic nickel laterite is not conducive to the improvement of sinter indices. Overall, the relatively better sintering performance of limonitic nickel laterite can be obtained at the self-possessed moisture of 21 mass $\%$ with tumble index, productivity and solid fuel rate of $48.87 \%$, $1.04 \mathrm{t} \mathrm{m}^{-2} \mathrm{~h}^{-1}$ and $136.52 \mathrm{~kg} \mathrm{t}^{-1}$, respectively. Furthermore, limonitic nickel laterite possesses excessively higher sinter mixture moisture (i.e., 17.35 mass \%) and vertical sintering speed (i.e., $32.78 \mathrm{~mm} \mathrm{~min}^{-1}$ ) compared to ordinary iron ores. Thus, even though the self-possessed moisture of limonitic nickel laterite is maintained at the optimum value (i.e., 21 mass $\%$ ), sintering performance of limonitic nickel laterite is still much poorer than that of ordinary iron ores.

\subsection{Effect of self-possessed moisture on metallurgical performance}

According to the results in Table 5, the chemical compositions of product sinter of limonitic nickel laterite at the different self-possessed moistures are similar in addition to the $\mathrm{FeO}$ content. When the self-possessed moisture of limonitic nickel laterite rises from 17 to 21 mass $\%$, the $\mathrm{FeO}$ content of product sinter is decreased from 24.39 to 20.89 mass \% due to the reduction in solid fuel consumption as shown in Fig. 3. Similarly, the FeO content of product sinter is gradually increased to 25.36 mass \% with the self-possessed moisture of limonitic nickel laterite further reaching 26 mass\%. Overall, the chemistry of product sinter of limonitic nickel laterite is characterized by lower iron and higher $\mathrm{FeO}, \mathrm{Cr}_{2} \mathrm{O}_{3}, \mathrm{Al}_{2} \mathrm{O}_{3}$ and $\mathrm{MgO}$ contents, which is one important reason for the poor sintering performance of limonitic nickel laterite [24, 25].

Table 6 demonstrates the self-possessed moisture of limonitic nickel laterite on the metallurgical performance of product sinter, including RI and RDI. As the self-possessed moisture of limonitic nickel laterite varies from 17 to 21 mass $\%$, the decreased $\mathrm{FeO}$ content of product sinter results in the improvement of RI from 78.66 to 85.40 mass \%, whereas RI is reduced to 75.49 mass \% when the self-possessed moisture is further increased to 26 mass\% due to the increase in $\mathrm{FeO}$ content of product sinter. In addition, RDI of product sinter is excellent regardless of the self-possessed moisture of limonitic nickel laterite with $\mathrm{RDI}_{-0.5 \mathrm{~mm}}$ below 2 mass\%, $\mathrm{RDI}_{+6.3 \mathrm{~mm}}$ above 85 mass $\%$ and $\mathrm{RDI}_{+3.15 \mathrm{~mm}}$ above 92 mass \%. This is mainly because the generation of inner stress in product sinter during the reduction process is greatly inhibited by the extremely high $\mathrm{FeO}$ content 
Table 5 Chemical compositions of product sinter

\begin{tabular}{|c|c|c|c|c|c|c|c|c|c|}
\hline \multirow[t]{2}{*}{ Self-possessed moisture/mass $\%$} & \multicolumn{8}{|c|}{ Chemical composition/mass $\%$} & \multirow[t]{2}{*}{ Basicity } \\
\hline & $\mathrm{TFe}$ & $\mathrm{FeO}$ & $\mathrm{NiO}$ & $\mathrm{Cr}_{2} \mathrm{O}_{3}$ & $\mathrm{SiO}_{2}$ & $\mathrm{CaO}$ & $\mathrm{Al}_{2} \mathrm{O}_{3}$ & $\mathrm{MgO}$ & \\
\hline 17 & 44.69 & 24.39 & 1.00 & 3.00 & 7.56 & 10.57 & 5.16 & 4.99 & 1.40 \\
\hline 19 & 44.81 & 22.64 & 1.00 & 3.02 & 7.50 & 10.48 & 5.13 & 5.01 & 1.40 \\
\hline 21 & 45.01 & 20.89 & 1.01 & 3.04 & 7.37 & 10.34 & 5.08 & 5.04 & 1.40 \\
\hline 23 & 44.74 & 23.12 & 1.00 & 3.01 & 7.54 & 10.53 & 5.15 & 5.00 & 1.40 \\
\hline 25 & 44.66 & 24.78 & 1.00 & 3.00 & 7.58 & 10.59 & 5.16 & 4.99 & 1.40 \\
\hline 26 & 44.59 & 25.36 & 1.00 & 2.99 & 7.62 & 10.64 & 5.18 & 4.98 & 1.40 \\
\hline
\end{tabular}

Table 6 Metallurgical performance of product sinter (mass\%)

\begin{tabular}{lllll}
\hline $\begin{array}{l}\text { Self-possessed } \\
\text { moisture }\end{array}$ & RI & \multicolumn{2}{l}{ RDI } & \\
\cline { 3 - 5 } & & RDI $_{+6.3 \mathrm{~mm}}$ & RDI $_{+3.15 \mathrm{~mm}}$ & RDI $_{-0.5 \mathrm{~mm}}$ \\
\hline 17 & 78.66 & 86.72 & 92.52 & 1.76 \\
19 & 80.98 & 88.56 & 93.37 & 1.45 \\
21 & 85.40 & 93.54 & 96.72 & 0.67 \\
23 & 82.64 & 91.55 & 95.06 & 1.17 \\
25 & 80.29 & 88.41 & 94.02 & 1.40 \\
26 & 75.49 & 85.91 & 93.29 & 1.33 \\
\hline
\end{tabular}

$(>20$ mass $\%)$ of product sinter $[26,27]$. At the optimum self-possessed moisture of 21 mass $\%$, the metallurgical performance of product sinter perfectly satisfies the requirements of blast furnace production.

\section{Discussion}

\subsection{Granulation properties of sinter mixture}

Table 7 compares the maximum molecular and capillary water of limonitic nickel laterite and ordinary iron ores. The maximum molecular water reflects the water holding capacity of fine ore particles, governed by the inherent pore properties [21, 22]. Limonitic nickel laterite possesses extremely higher content of the maximum molecular water compared with ordinary iron ores due to its highly porous texture. The maximum capillary water indicates the water absorption capacity of naturally piled powder bed. As confirmed in Fig. 1b, the hydrophility of limonitic nickel laterite is excellent due to its rough surface and loose texture, leading to the much higher level of the maximum capillary water. Thus, the sinter mixture moisture of limonitic nickel laterite should be far higher than that of
Table 7 Comparison of maximum molecular and capillary water contents (mass\%)

\begin{tabular}{lll}
\hline Sample & $\begin{array}{l}\text { Maximum molecular } \\
\text { water content }\end{array}$ & $\begin{array}{l}\text { Maximum capillary } \\
\text { water content }\end{array}$ \\
\hline $\begin{array}{l}\text { Ordinary iron ore } \\
{[21,22]}\end{array}$ & $1.42-11.96$ & $11.41-21.14$ \\
$\begin{array}{l}\text { Limonitic nickel } \\
\text { laterite }\end{array}$ & 23.98 & 36.75 \\
\hline
\end{tabular}

ordinary iron ores, nicely agreeing with the results of Fig. 2.

In the granulation process, sinter mixture particles are made into the granules with appropriate moisture and reasonable size distributions during rolling, which is mainly dominated by the action of capillary force formed between water and sinter mixture particles [28, 29]. Capillary water plays a key role in granulating and its migration rate determines the pelletizing efficiency of sinter mixture. Limonitic nickel laterite exhibits the loose porous structure, excellent hydrophilicity and high moisture absorption capacity. As the self-possessed moisture of limonitic nickel laterite is increased, the internal pores would be gradually filled by the redundant physical water, contributing to the migration of capillary water between the particles of limonitic nickel laterite [16-19]. Subsequently, the optimum moisture of sinter mixture also rises with the self-possessed moisture of limonitic nickel laterite due to the faster migration rate of capillary water under the same granulating parameters, which is in accordance with the results in Fig. 3. Thus, the aggregation of particles is obviously improved, and more large particles above +3 $\mathrm{mm}$ in sinter mixture are formed with the increase in the self-possessed moisture of limonitic nickel laterite, as shown in Fig. 5. This would promote the increase in vertical sintering speed, which is consistent with the results in Fig. 4. However, the over-fast sintering speed is adverse to the sinter consolidation, and the excessively higher sinter 
mixture moisture may lead to more solid fuel consumption during sintering. The self-possessed moisture of limonitic nickel laterite should be maintained at an appropriate value. As described in Fig. 5, drop strength of sinter mixture represents the aggregated effectiveness of the granulated particles, which is characterized by the $-0.5 \mathrm{~mm}$ fraction of sinter mixture after dropping. The higher value of the $-0.5 \mathrm{~mm}$ fraction indicates the poorer drop strength of sinter mixture. With the self-possessed moisture of limonitic nickel laterite rising from 17 to 21 mass $\%$, the $-0.5 \mathrm{~mm}$ fraction of sinter mixture after dropping is decreased from 8.73 to 2.58 mass $\%$, while it is increased to 9.52 mass $\%$ when the self-possessed moisture of limonitic nickel laterite further reaches 26 mass $\%$. Hence, the optimum drop strength of sinter mixture is obtained as the selfpossessed moisture of limonitic nickel laterite is maintained at 21 mass \%. At the higher or lower self-possessed moisture of limonitic nickel laterite, the granulated particles cannot be commendably aggregated and are simply connected with each other under the action of water, which would significantly weaken sinter strength. Combined with the above analyses, the recommended self-possessed moisture of limonitic nickel laterite should be 21 mass $\%$, perfectly in accordance with the descriptions of Fig. 4.

\subsection{Thermodynamic conditions during sintering}

Generally, the maximum exhaust-gas temperature is used to reflect the thermodynamic conditions during sintering. The higher level of the maximum exhaust-gas temperature signifies the higher sintering temperature and longer holding time of high temperature, which is beneficial to sinter consolidation. Figure 6 shows the variation of the maximum exhaust-gas temperature during sintering with the self-possessed moisture of limonitic nickel laterite. As the self-possessed moisture of limonitic nickel laterite is

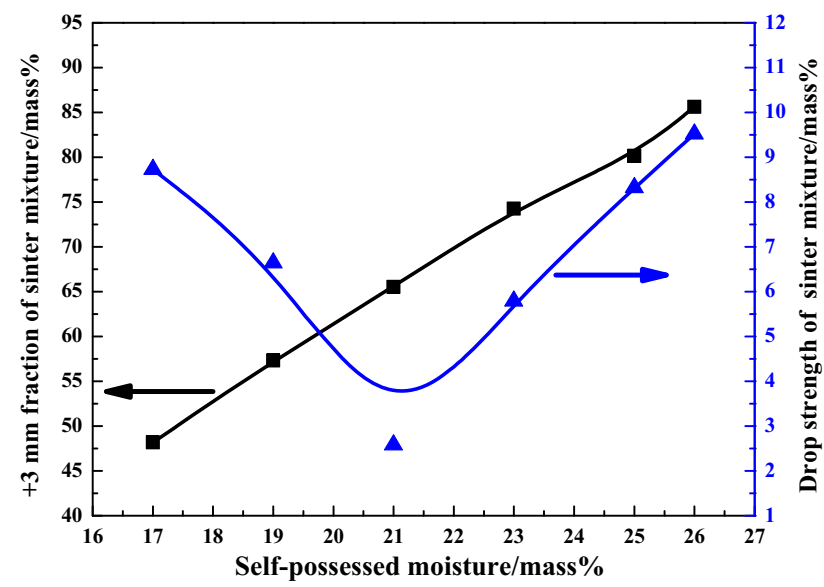

Fig. 5 Variations of $+3 \mathrm{~mm}$ fraction and drop strength of sinter mixture increased from 17 to 21 mass $\%$, the maximum exhaust-gas temperature is significantly increased from 237 to $289^{\circ} \mathrm{C}$, and the thermodynamic conditions during sintering are obviously improved. This is mainly due to the fact that the reasonable increase in the self-possessed moisture of limonitic nickel laterite contributes to the higher optimum moisture and drop strength of sinter mixture, which effectively improves the thermal conductivity and heat transfer efficiency of sinter bed. However, when the selfpossessed moisture of limonitic nickel laterite further rises to 26 mass \%, the maximum exhaust-gas temperature is dramatically lowered to $208{ }^{\circ} \mathrm{C}$. As confirmed in previous studies [30,31], the decomposition of the abundant crystal water in limonitic nickel laterite during sintering would result in the formation of highly porous sinter, which subsequently leads to rather low heat front velocity. This adversely affects the transformation of the heat supplied by the combustion of anthracite to sinter bed in the high temperature zone and the efficient utilization of hightemperature exhaust-gas in the lower part. Finally, the asynchrony of the heat front velocity and combustion front velocity leads to the formation of the high-temperature zone with large thickness and low temperature during sintering, and hence, the demand of the sintering mineralization cannot be commendably satisfied. The increase in the self-possessed moisture of limonitic nickel laterite from 21 to 26 mass \% leads to the further increase in the overfast vertical sintering speed from 32.78 to $38.14 \mathrm{~mm} \mathrm{~min}^{-1}$ and then exacerbates the asynchrony of the heat front velocity and combustion front velocity. Therefore, the thermodynamic conditions during sintering are relatively superior as the self-possessed moisture of limonitic nickel laterite is 21 mass\%, which is consistent with the results of Fig. 4. However, even at the optimum self-possessed moisture of limonitic nickel laterite, the

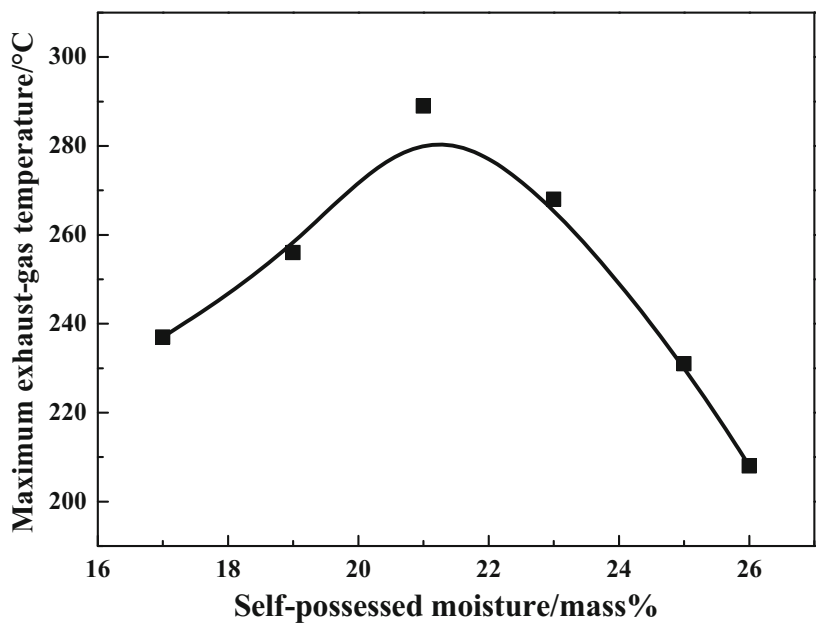

Fig. 6 Variation of maximum exhaust-gas temperature during sintering 
maximum exhaust-gas temperature during sintering is only $289^{\circ} \mathrm{C}$, far lower than that of ordinary iron ores. This is another important reason for the poor sintering performance of limonitic nickel laterite.

\subsection{Mineralogy of product sinter}

\subsubsection{Pore structure characteristics}

Figure 7 describes the pore structure characteristics of product sinter at the different self-possessed moistures of limonitic nickel laterite. As the self-possessed moisture rises from 17 to 21 mass\%, the pore size is gradually decreased and sinter porosity is correspondingly reduced from $53.92 \%$ to $45.29 \%$ in area fraction (Table 8 ) due to the effective improvement in granulation properties and thermodynamic conditions during sintering, thereby improving sinter strength. However, when the self-possessed moisture is further elevated to 26 mass $\%$, much larger sinter pores are formed through the coalescence, and sinter porosity is sharply increased to $59.45 \%$ in area fraction, which is greatly adverse to sinter strength. In addition, product sinter of limonitic nickel laterite is always characterized by large thin-wall pores regardless of its self-possessed moisture, and sinter porosity reaches as high as $45.29 \%$ in area fraction even at the optimum selfpossessed moisture of 21 mass $\%$. This indicates that sinter strength of limonitic nickel laterite should be far poorer than that of ordinary iron ores.

\subsubsection{Consolidation mechanism}

As confirmed in Figs. 8 and 9 and Table 9, solid phases in product sinter are mainly in the form of hercynite, a small amount of Cr-spinel and nickel-ferric spinel, whereas liquid phases are composed of eutectic spinel olivine and silico-ferrite of calcium and alumina (SFCA). Hercynite as the major solid phase is formed by the partial substitution of $\mathrm{Mg}^{2+}$ or $\mathrm{Al}^{3+}$ ions for $\mathrm{Fe}^{2+}$ or $\mathrm{Fe}^{3+}$ ions [32, 33], which exists in granular, tabular and dispersive textures described
Table 8 Porosity of product sinter

\begin{tabular}{llll}
\hline Self-possessed moisture/mass $\%$ & 17 & 21 & 26 \\
\hline Sinter porosity in area fraction/\% & 53.92 & 45.29 & 59.45 \\
\hline
\end{tabular}

as $(\mathrm{Fe}, \mathrm{Mg}) \mathrm{Fe}_{2} \mathrm{O}_{4}, \mathrm{Fe}(\mathrm{Fe}, \mathrm{Al})_{2} \mathrm{O}_{4}$ and $(\mathrm{Fe}, \mathrm{Mg}) \cdot(\mathrm{Fe}, \mathrm{Al})_{2} \mathrm{O}_{4}$, respectively. Similarly, nubbly $\mathrm{Cr}$-spinel and granular nickel-ferric spinel are formed with sporadic distribution. Eutectic spinel olivine is generated by the eutectic reaction of kirschsteinite (CaO-FeO- $\left.\mathrm{SiO}_{2}\right)$, monticellite $\left(\mathrm{CaO} \cdot \mathrm{MgO} \cdot \mathrm{SiO}_{2}\right)$ and fayalite $\left(2 \mathrm{FeO} \cdot \mathrm{SiO}_{2}\right)$ with hercynite in different proportions [9] and identified as three types, i.e., $\mathrm{CaO} \cdot(\mathrm{Fe}, \mathrm{Mg}) \mathrm{Al}_{2} \mathrm{O}_{4} \cdot \mathrm{SiO}_{2}, \mathrm{CaO} \cdot \mathrm{FeAl}_{2} \mathrm{O}_{4} \cdot \mathrm{SiO}_{2}$ and $\mathrm{CaO} \cdot(\mathrm{Fe}, \mathrm{Mg}) \mathrm{Fe}_{2} \mathrm{O}_{4} \cdot \mathrm{SiO}_{2}$. SFCA mainly exhibits dendritic and tabular textures and is considered as the most desirable bonding phase due to its high reducibility and mechanical strength [34-36]. Overall, the mineral types in product sinter including solid and liquid phases are similar regardless of the self-possessed moisture of limonitic nickel laterite.

In addition, SFCA in product sinter is always formed at the edge of pores with less amount at the self-possessed moisture of 17 mass\% and especially 26 mass\%, which is extremely unfavorable to sinter consolidation. However, as the self-possessed moisture is maintained at 21 mass $\%$, SFCA is gradually extended to the interior of product sinter along the edge of the pores, and its amount is obviously increased due to the significant improvement in heat and mass transfer conditions during sintering. Furthermore, it can be observed that hercynite cannot be efficiently bonded by liquid phases such as SFCA and eutectic spinel olivine with limited grain size, poor interconnection and scattered distribution when the self-possessed moisture of limonitic nickel laterite is inappropriate (17 or 26 mass\%). Nevertheless, the granulation properties and thermodynamic conditions during sintering are relatively better at the optimum self-possessed moisture of 21 mass $\%$ as investigated in Figs. 5 and 6, which contributes to the aggregation

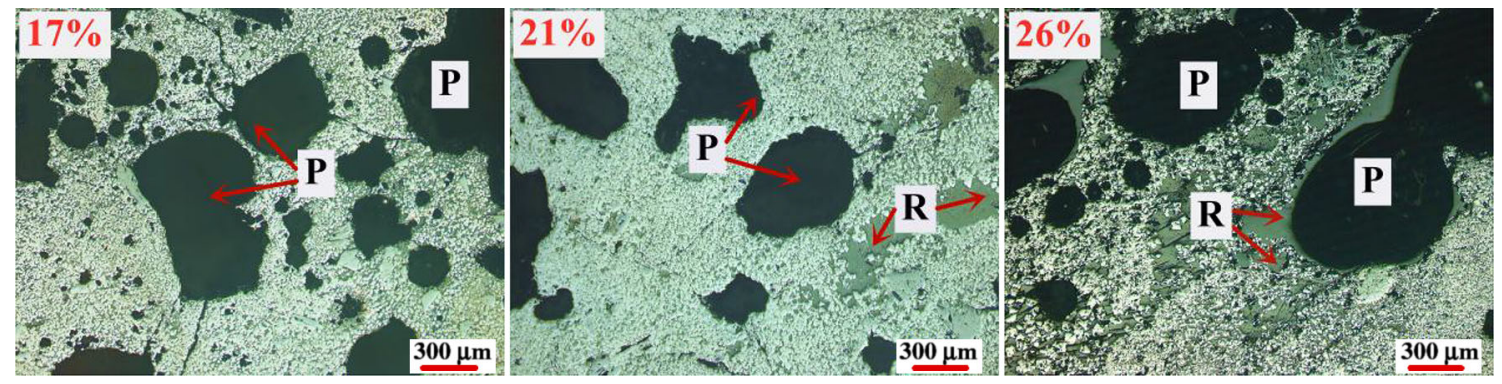

Fig. 7 Pore structure characteristics of product sinter with various self-possessed moisture of limonitic nickel laterite under OM. P Pore; R resin 

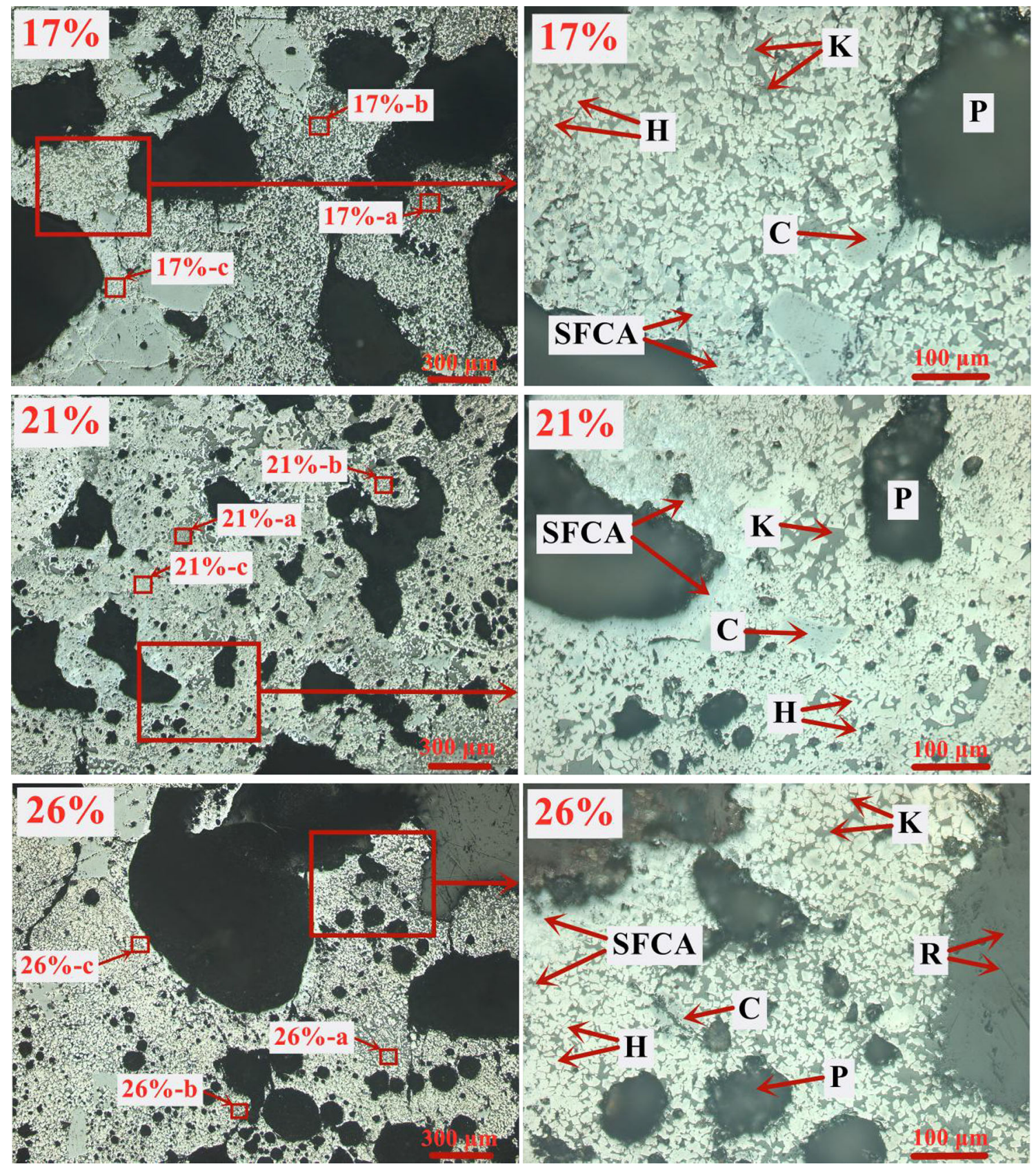

Fig. 8 Microstructure of product sinter under OM with different self-possessed moisture of limonitic nickel laterite. H Hercynite; K olivine phase; $\mathrm{C}-\mathrm{Cr}$ spinel

and growth of hercynite grains and the diffusion of particles in solid-phase and liquid-phase reactions. Just as shown in Figs. 8 and 9, the size and interconnection of hercynite grains are obviously improved as well as the adhesion between solid phases and liquid phases. Thus, sinter strength should be much better at the self-possessed moisture of 21 mass \%, exactly agreeing with the results of Fig. 4.
Table 10 summarizes the mineral compositions of product sinter of limonitic nickel laterite at its different selfpossessed moisture. The increase in the self-possessed moisture of limonitic nickel laterite from 17 to 21 mass\% contributes to the formation of SFCA with its amount elevated from $6.36 \%$ to $10.24 \%$ in area fraction and then the improvement of sinter strength. This is mainly because the decrease in solid fuel rate and $\mathrm{FeO}$ content of product sinter, and the improved granulation properties and 


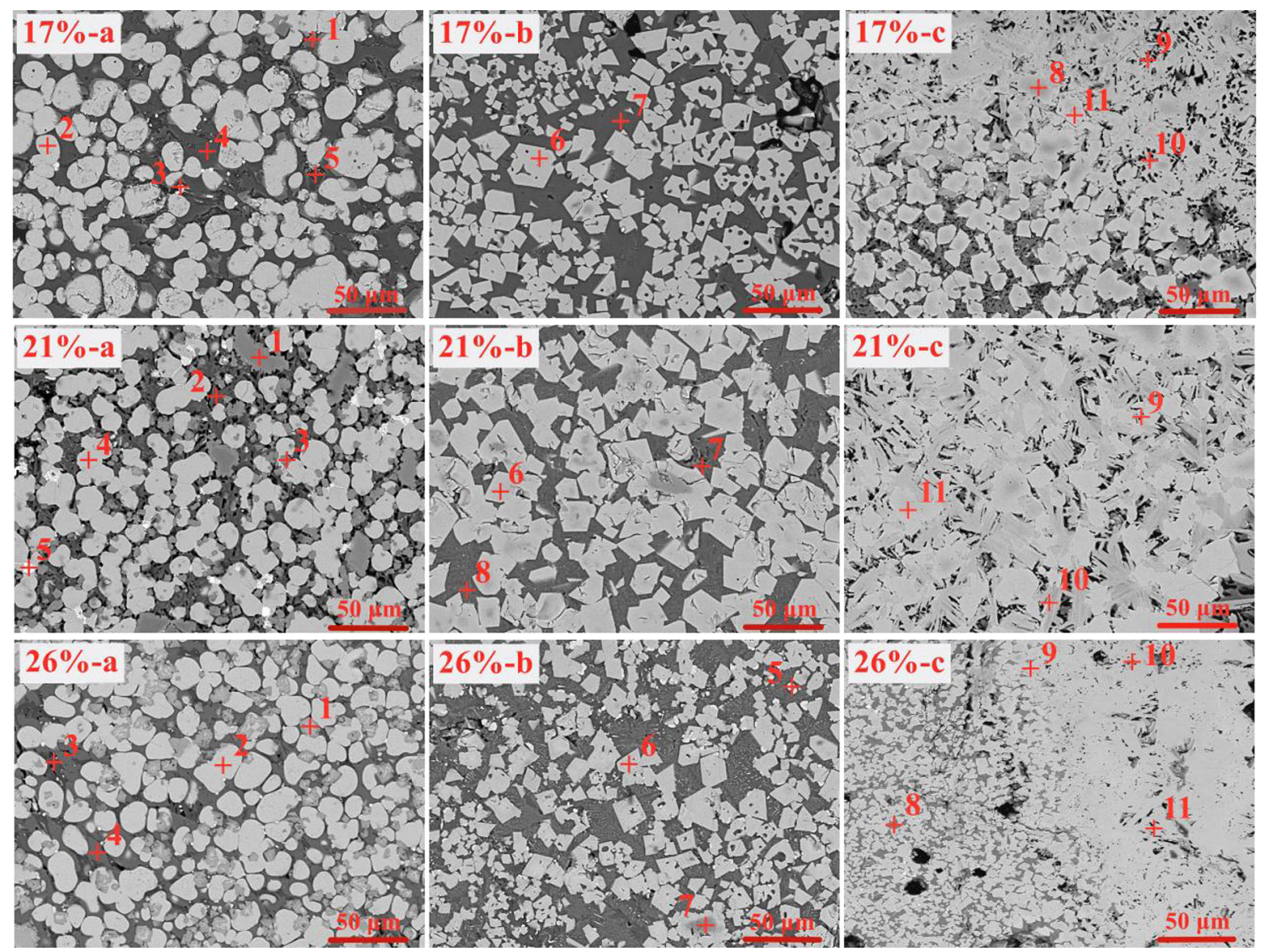

Fig. 9 Microstructure of product sinter under SEM with different self-possessed moistures of limonitic nickel laterite. a-c are selected areas in Fig. 8 covering all typical morphology areas of product sinter

thermodynamic conditions during sintering provide the better formation conditions for SFCA. Similarly, the amount of SFCA formed is greatly reduced to $3.19 \%$ in area fraction when the self-possessed moisture further reaches 26 mass\%. Overall, sintering performance of limonitic nickel laterite should be better at the optimum self-possessed moisture of 21 mass\% due to the relatively more SFCA amount and tighter sinter microstructure. However, the flame front speed of sinter bed and sinter porosity still reach as high as $32.78 \mathrm{~mm} \mathrm{~min}^{-1}$ and $45.29 \%$ in area fraction, whereas the maximum exhaust-gas temperature during sintering and SFCA amount are only $289{ }^{\circ} \mathrm{C}$ and $10.24 \%$ in area fraction, respectively, which leads to the much poorer sintering performance of limonitic nickel laterite compared to that of ordinary ores. In addition, the metallurgical performance of product sinter is excellent for blast furnace production. Thus, on the premise of the optimum self-possessed moisture of 21 mass $\%$, if limonitic nickel laterite sintering can be effectively strengthened by inhibiting the over-fast sintering speed and improving the thermodynamic conditions during sintering, product sinter of limonitic nickel laterite will become a more desirable blast furnace burden for stainless steel production.

\section{Conclusions}

1. With the optimization of the self-possessed moisture of limonitic nickel laterite, relatively better sinter indices are obtained with tumble index, productivity and solid fuel rate of $48.87 \%, \quad 1.04 \mathrm{t} \mathrm{m}^{-2} \mathrm{~h}^{-1}$ and $136.52 \mathrm{~kg} \mathrm{t}^{-1}$, respectively, as the self-possessed moisture of limonitic nickel laterite is 21 mass\%. RI and $\mathrm{RDI}_{+3.15 \mathrm{~mm}}$ of product sinter reach as high as 85.40 and 96.72 mass\%, respectively, meeting the requirements of blast furnace production.

2. When the self-possessed moisture of limonitic nickel laterite is maintained at 21 mass $\%$, the granulation properties of sinter mixture are more appropriate with higher drop strength, and the thermodynamic conditions during sintering is relatively better, contributing to the improvement of sintering performance of limonitic nickel laterite. 
Table 9 EDS analysis results for areas in Fig. 9

\begin{tabular}{|c|c|c|c|c|c|c|c|c|c|}
\hline \multirow[t]{2}{*}{ Area No. } & \multicolumn{8}{|c|}{ Elemental compositions/at.\% } & \multirow[t]{2}{*}{ Mineral phase } \\
\hline & $\mathrm{Fe}$ & $\mathrm{Cr}$ & $\mathrm{Ni}$ & $\mathrm{Mg}$ & $\mathrm{Al}$ & $\mathrm{Si}$ & $\mathrm{Ca}$ & $\mathrm{O}$ & \\
\hline $17 \%-1$ & 32.80 & 0.25 & 0.34 & 4.09 & 3.58 & 0.28 & 0.31 & 58.35 & $(\mathrm{Fe}, \mathrm{Mg}) \cdot(\mathrm{Fe}, \mathrm{Al})_{2} \mathrm{O}_{4}$ \\
\hline $17 \%-2$ & 36.28 & 0.16 & 0.11 & 3.61 & 0.21 & 0.50 & 0.38 & 58.75 & $(\mathrm{Fe}, \mathrm{Mg}) \mathrm{Fe}_{2} \mathrm{O}_{4}$ \\
\hline $17 \%-3$ & 31.36 & 0.08 & 16.92 & 0.24 & 0.33 & 0.07 & 0.09 & 50.91 & $\mathrm{NiFe}_{2} \mathrm{O}_{4}$ \\
\hline $17 \%-4$ & 12.18 & 0.14 & 0.08 & 4.39 & 0.24 & 15.49 & 16.24 & 51.24 & $\mathrm{CaO} \cdot(\mathrm{Fe}, \mathrm{Mg}) \mathrm{Fe}_{2} \mathrm{O}_{4} \cdot \mathrm{SiO}_{2}$ \\
\hline $17 \%-5$ & 13.89 & 0.17 & 0.21 & 0.61 & 5.33 & 14.08 & 15.23 & 50.48 & $\mathrm{CaO} \cdot \mathrm{FeAl}_{2} \mathrm{O}_{4} \cdot \mathrm{SiO}_{2}$ \\
\hline $17 \%-6$ & 36.39 & 0.37 & 0.29 & 0.32 & 4.07 & 0.14 & 0.17 & 58.25 & $\mathrm{Fe}(\mathrm{Fe}, \mathrm{Al})_{2} \mathrm{O}_{4}$ \\
\hline $17 \%-7$ & 12.76 & 0.12 & 0.06 & 3.55 & 3.08 & 14.06 & 15.52 & 50.85 & $\mathrm{CaO} \cdot(\mathrm{Fe}, \mathrm{Mg}) \mathrm{Al}_{2} \mathrm{O}_{4} \cdot \mathrm{SiO}_{2}$ \\
\hline $17 \%-8$ & 20.68 & 13.98 & 0.22 & 5.04 & 8.44 & 0.17 & 0.40 & 51.07 & $(\mathrm{Fe}, \mathrm{Mg}) \cdot(\mathrm{Cr}, \mathrm{Fe}, \mathrm{Al})_{2} \mathrm{O}_{4}$ \\
\hline $17 \%-9$ & 32.98 & 0.19 & 0.07 & 0.36 & 3.17 & 4.68 & 7.03 & 51.52 & SFCA \\
\hline $17 \%-10$ & 31.26 & 0.18 & 0.12 & 0.57 & 4.56 & 5.72 & 7.48 & 50.11 & SFCA \\
\hline $17 \%-11$ & 32.94 & 0.25 & 0.13 & 3.22 & 4.12 & 0.74 & 0.15 & 58.45 & $(\mathrm{Fe}, \mathrm{Mg}) \cdot(\mathrm{Fe}, \mathrm{Al})_{2} \mathrm{O}_{4}$ \\
\hline $21 \%-1$ & 19.18 & 15.47 & 0.32 & 4.94 & 5.95 & 0.21 & 0.28 & 53.65 & $(\mathrm{Fe}, \mathrm{Mg}) \cdot(\mathrm{Cr}, \mathrm{Fe}, \mathrm{Al})_{2} \mathrm{O}_{4}$ \\
\hline $21 \%-2$ & 13.51 & 0.09 & 0.14 & 3.68 & 3.58 & 14.07 & 14.76 & 50.17 & $\mathrm{CaO} \cdot(\mathrm{Fe}, \mathrm{Mg}) \mathrm{Al}_{2} \mathrm{O}_{4} \cdot \mathrm{SiO}_{2}$ \\
\hline $21 \%-3$ & 32.09 & 0.26 & 0.05 & 3.87 & 4.51 & 0.29 & 0.37 & 58.56 & $(\mathrm{Fe}, \mathrm{Mg}) \cdot(\mathrm{Fe}, \mathrm{Al})_{2} \mathrm{O}_{4}$ \\
\hline $21 \%-4$ & 36.54 & 0.12 & 0.28 & 3.80 & 0.60 & 0.21 & 0.35 & 58.10 & $(\mathrm{Fe}, \mathrm{Mg}) \mathrm{Fe}_{2} \mathrm{O}_{4}$ \\
\hline $21 \%-5$ & 30.67 & 0.28 & 17.11 & 0.42 & 0.45 & 0.38 & 0.53 & 50.16 & $\mathrm{NiFe}_{2} \mathrm{O}_{4}$ \\
\hline $21 \%-6$ & 36.05 & 0.21 & 0.13 & 0.37 & 5.62 & 0.25 & 0.31 & 57.06 & $\mathrm{Fe}(\mathrm{Fe}, \mathrm{Al})_{2} \mathrm{O}_{4}$ \\
\hline $21 \%-7$ & 12.62 & 0.14 & 0.13 & 0.61 & 4.82 & 14.20 & 16.33 & 51.15 & $\mathrm{CaO} \cdot \mathrm{FeAl}_{2} \mathrm{O}_{4} \cdot \mathrm{SiO}_{2}$ \\
\hline $21 \%-8$ & 13.23 & 0.35 & 0.21 & 3.44 & 0.19 & 14.52 & 16.05 & 52.01 & $\mathrm{CaO} \cdot(\mathrm{Fe}, \mathrm{Mg}) \mathrm{Fe}_{2} \mathrm{O}_{4} \cdot \mathrm{SiO}_{2}$ \\
\hline $21 \%-9$ & 32.88 & 0.47 & 0.36 & 0.67 & 3.70 & 4.56 & 6.80 & 50.56 & SFCA \\
\hline $21 \%-10$ & 31.39 & 0.40 & 0.18 & 4.39 & 4.65 & 0.16 & 0.45 & 58.38 & $(\mathrm{Fe}, \mathrm{Mg}) \cdot(\mathrm{Fe}, \mathrm{Al})_{2} \mathrm{O}_{4}$ \\
\hline $21 \%-11$ & 31.52 & 0.23 & 0.24 & 0.26 & 5.17 & 5.37 & 7.15 & 50.06 & SFCA \\
\hline $26 \%-1$ & 31.36 & 0.32 & 0.20 & 4.11 & 4.62 & 0.12 & 0.33 & 58.94 & $(\mathrm{Fe}, \mathrm{Mg}) \cdot(\mathrm{Fe}, \mathrm{Al})_{2} \mathrm{O}_{4}$ \\
\hline $26 \%-2$ & 36.62 & 0.19 & 0.23 & 3.43 & 0.57 & 0.11 & 0.17 & 58.68 & $(\mathrm{Fe}, \mathrm{Mg}) \mathrm{Fe}_{2} \mathrm{O}_{4}$ \\
\hline $26 \%-3$ & 13.19 & 0.16 & 0.17 & 0.53 & 4.61 & 13.65 & 15.81 & 51.88 & $\mathrm{CaO} \cdot \mathrm{FeAl}_{2} \mathrm{O}_{4} \cdot \mathrm{SiO}_{2}$ \\
\hline $26 \%-4$ & 13.58 & 0.13 & 0.08 & 4.24 & 0.16 & 14.64 & 16.05 & 51.12 & $\mathrm{CaO} \cdot(\mathrm{Fe}, \mathrm{Mg}) \mathrm{Fe}_{2} \mathrm{O}_{4} \cdot \mathrm{SiO}_{2}$ \\
\hline $26 \%-5$ & 30.27 & 0.38 & 16.59 & 0.53 & 0.66 & 0.34 & 0.25 & 50.98 & $\mathrm{NiFe}_{2} \mathrm{O}_{4}$ \\
\hline $26 \%-6$ & 35.77 & 0.37 & 0.40 & 0.39 & 5.06 & 0.22 & 0.32 & 57.47 & $\mathrm{Fe}(\mathrm{Fe}, \mathrm{Al})_{2} \mathrm{O}_{4}$ \\
\hline $26 \%-7$ & 18.86 & 18.94 & 0.43 & 5.30 & 4.04 & 0.16 & 0.20 & 52.07 & $(\mathrm{Fe}, \mathrm{Mg}) \cdot(\mathrm{Cr}, \mathrm{Fe}, \mathrm{Al})_{2} \mathrm{O}_{4}$ \\
\hline $26 \%-8$ & 13.62 & 0.21 & 0.08 & 2.38 & 4.17 & 14.24 & 15.04 & 50.26 & $\mathrm{CaO} \cdot(\mathrm{Fe}, \mathrm{Mg}) \mathrm{Al}_{2} \mathrm{O}_{4} \cdot \mathrm{SiO}_{2}$ \\
\hline $26 \%-9$ & 32.17 & 0.36 & 0.31 & 3.30 & 4.41 & 0.19 & 0.54 & 58.72 & $(\mathrm{Fe}, \mathrm{Mg}) \cdot(\mathrm{Fe}, \mathrm{Al})_{2} \mathrm{O}_{4}$ \\
\hline $26 \%-10$ & 32.79 & 0.32 & 0.25 & 0.82 & 3.29 & 4.84 & 6.36 & 51.33 & SFCA \\
\hline $26 \%-11$ & 31.74 & 0.18 & 0.11 & 0.28 & 4.14 & 5.45 & 7.18 & 50.92 & SFCA \\
\hline
\end{tabular}

3. As the self-possessed moisture of limonitic nickel laterite is adjusted to the optimum value of 21 mass $\%$, sinter porosity is reduced to $45.29 \%$ and SFCA amount is increased to $10.24 \%$ in area fraction. In addition, the bonding effectiveness between hercynite and liquid phases including SFCA and eutectic spinel olivine is comparatively better with the aggregation and growth of hercynite grains. Thus, relatively better sintering performance of limonitic nickel laterite can be obtained.

4. Even at the optimum self-possessed moisture of limonitic nickel laterite, its sintering performance is still much poorer than that of ordinary ores. Limonitic nickel laterite sintering is expected to be effectively strengthened by inhibiting the over-fast sintering speed and improving the thermodynamic conditions during sintering. 
Table 10 Mineral compositions of product sinter in area fraction/\%

\begin{tabular}{|c|c|c|c|c|c|c|c|c|c|}
\hline \multirow[t]{3}{*}{ No. } & \multicolumn{5}{|c|}{ Solid phase } & \multicolumn{4}{|c|}{ Liquid phase } \\
\hline & \multicolumn{3}{|c|}{ Hercynite } & \multirow[t]{2}{*}{ Cr-spinel } & \multirow[t]{2}{*}{ Nickel-ferric spinel } & \multicolumn{3}{|c|}{ Eutectic olivine phase } & \multirow[t]{2}{*}{$\mathrm{SFCA}$} \\
\hline & $\mathrm{H}$ & $\mathrm{H}-1$ & $\mathrm{H}-2$ & & & $\mathrm{~K}$ & $\mathrm{~K}-1$ & $\mathrm{~K}-2$ & \\
\hline $17 \%$ & 15.27 & 24.64 & 23.12 & 2.58 & 1.10 & 12.28 & 5.73 & 8.92 & 6.36 \\
\hline $21 \%$ & 17.59 & 20.71 & 22.49 & 2.62 & 1.12 & 16.54 & 2.27 & 6.42 & 10.24 \\
\hline $26 \%$ & 13.88 & 26.63 & 24.51 & 2.59 & 1.09 & 11.36 & 7.69 & 9.06 & 3.19 \\
\hline
\end{tabular}

$\mathrm{H}(\mathrm{Fe}, \mathrm{Mg}) \cdot(\mathrm{Fe}, \mathrm{Al})_{2} \mathrm{O}_{4} ; \mathrm{H}-1 \mathrm{Fe}(\mathrm{Fe}, \mathrm{Al})_{2} \mathrm{O}_{4} ; \mathrm{H}-2(\mathrm{Fe}, \mathrm{Mg}) \mathrm{Fe}_{2} \mathrm{O}_{4} ; \mathrm{K} \mathrm{CaO} \cdot(\mathrm{Fe}, \mathrm{Mg}) \mathrm{Al}_{2} \mathrm{O}_{4} \cdot \mathrm{SiO}_{2} ; \mathrm{K}-1 \mathrm{CaO} \cdot \mathrm{FeAl} \mathrm{O}_{4} \cdot \mathrm{SiO}_{2} ; \mathrm{K}-2 \mathrm{CaO} \cdot(\mathrm{Fe}$, $\mathrm{Mg}) \mathrm{Fe}_{2} \mathrm{O}_{4} \cdot \mathrm{SiO}_{2}$

Acknowledgements Financial support from the Major Project of Master Alloy Manufacture for Heat Resistant Stainless Steel Production (No. AA18242003) funded by the Provincial Government of Guangxi Zhuang Autonomous District is sincerely acknowledged.

Open Access This article is licensed under a Creative Commons Attribution 4.0 International License, which permits use, sharing, adaptation, distribution and reproduction in any medium or format, as long as you give appropriate credit to the original author(s) and the source, provide a link to the Creative Commons licence, and indicate if changes were made. The images or other third party material in this article are included in the article's Creative Commons licence, unless indicated otherwise in a credit line to the material. If material is not included in the article's Creative Commons licence and your intended use is not permitted by statutory regulation or exceeds the permitted use, you will need to obtain permission directly from the copyright holder. To view a copy of this licence, visit http://creativecommons. org/licenses/by/4.0/

\section{References}

[1] W.J. Wei, P.B. Samuelsson, A. Tilliander, R. Gyllenram, P.G. Jönsson, Energies 13 (2020) 5664.

[2] X.T. Ma, D.L. Yang, Y.J. Zhai, X.X. Shen, R.R. Zhang, J.L. Hong, Int. J. Life Cycle Assess. 24 (2019) 1840-1850.

[3] R.M. Shi, X.M. Li, Y.R. Cui, J.X. Zhao, C. Zuo, G.B. Qiu, Materials 13 (2020) 4992.

[4] S. Çetintaş, U. Yildiz, D. Bingöl, J. Clean. Prod. 199 (2018) 616-632.

[5] G. Mongelli, B. Taghipour, R. Sinisi, S. Khadivar, Ore Geol. Rev. 111 (2019) 102990.

[6] X.W. Lv, C.G. Bai, S.P. He, Q.Y. Huang, ISIJ Int. 50 (2010) 380-385.

[7] R.A. Bergman, Cim. Bull. 96 (2003) 127-138.

[8] M.X. Liu, C.G. Wang, J. Luo, M.J. Rao, G.H. Li, T. Jiang, JOM 71 (2019) 3181-3189.

[9] D.Q. Zhu, Y.X. Xue, J. Pan, C.C. Yang, Z.Q. Guo, H.Y. Tian, H. Liao, L.T. Pan, X.Z. Huang, Powder Technol. 367 (2020) 616-631.

[10] D.Q. Zhu, Y.X. Xue, J. Pan, C.C. Yang, Z.Q. Guo, H.Y. Tian, X. Wang, Q.Z. Huang, L.T. Pan, X.Z. Huang, Powder Technol. 373 (2020) 727-740.

[11] E. Keskinkilic, Metals 9 (2019) 974.

[12] L.T. Pan, J. Yang, Y.B. Xu, Sinter. Pellet. 38 (2013) No. 2, 25-27.

[13] B. Quesnel, C.L.C. de Veslud, P. Boulvais, P. Gautier, M. Cathelineau, M. Drouillet, Miner. Deposita 52 (2017) 961-978.
[14] W. Fu, Y.M. Zhang, C.J. Pang, X.W. Zeng, X.R. Huang, M.L. Yang, Y. Shao, H. Lin, J. Geochem. Explor. 188 (2018) 240-256.

[15] Q. Huang, X. Lv, J. Min. Metall. B Metall. 47 (2011) 45-51.

[16] X.B. Huang, X.W. Lv, C.G. Bai, G.B. Qiu, L.M. Lu, ISIJ Int. 54 (2014) 2721-2727.

[17] T. Higuchi, L.M. Lu, E. Kasai, T. Yamamoto, H. Matsuno, Powder Technol. 339 (2018) 550-559.

[18] X.W. Lv, C.G. Bai, G.B. Qiu, M.L. Hu, Powder Technol. 204 (2010) 138-144.

[19] T. Higuchi, L.M. Lu, E. Kasai, ISIJ Int. 57 (2017) 1384-1393.

[20] Y.X. Xue, D.Q. Zhu, J. Pan, Z.Q. Guo, C.C. Yang, H.Y. Tian, X. Duan, Q.Z. Huang, L.T. Pan, X.Z. Huang, Minerals 10 (2020) 750.

[21] C.C. Yang, D.Q. Zhu, B.J. Shi, J. Pan, L.M. Lu, X.B. Li, Y.P. Mo, J. Iron Steel Res. Int. 24 (2017) 1007-1015.

[22] J. Pan, B.J. Shi, D.Q. Zhu, Y.P. Mo, ISIJ Int. 56 (2016) 777-785.

[23] G.Z. Qiu, T. Jiang, X.H. Fan, D.Q. Zhu, Z.C. Huang, Scand. J. Metall. 33 (2004) 39-46.

[24] M.K. Kalenga, A.M. Garbers-Craig, J. South Afr. Inst. Min. Metall. 110 (2010) 447-456.

[25] M.I. Pownceby, N.A.S. Webster, J.R. Manuel, N. Ware, Miner. Process. Extr. Metall. Section C 125 (2016) 140-148.

[26] N. Takeuchi, Y. Iwami, T. Higuchi, K. Nushiro, N. Oyama, M. Sato, ISIJ Int. 54 (2014) 791-800.

[27] M. Mizutani, T. Nishimura, T. Orimoto, K. Higuchi, S. Nomura, K. Saito, E. Kasai, ISIJ Int. 57 (2017) 1499-1508.

[28] C.C. Yang, D.Q. Zhu, J. Pan, L.M. Lu, ISIJ Int. 58 (2018) $1427-1436$.

[29] A.M. Nyembwe, R.D. Cromarty, A.M. Garbers-Craig, Powder Technol. 295 (2016) 7-15.

[30] Y.Z. Wang, J.L. Zhang, Z.J. Liu, Y.P. Zhang, D.H. Liu, Y.R. Liu, Int. J. Miner. Metall. Mater. 24 (2017) 1087-1095.

[31] C.E. Loo, N. Tame, G.C. Penny, ISIJ Int. 52 (2012) 967-976.

[32] X.F. Ding, H.Z. Zhao, Z.D. Xiang, H. Zhang, Q. He, J.J. Li, Ceram. Int. 42 (2016) 19058-19062.

[33] P. Jiang, J.H. Chen, M.W. Yan, B. Li, J.D. Su, X.M. Hou, Int. J. Miner. Metall. Mater. 22 (2015) 1219-1224.

[34] H. Guo, X.M. Guo, Metall. Mater. Trans. B 49 (2018) 1974-1984.

[35] N.A.S. Webster, M.I. Pownceby, I.C. Madsen, A.J. Studer, J.R. Manuel, J.A. Kimpton, Metall. Mater. Trans. B 45 (2014) 2097-2105.

[36] D.H. Liu, H. Liu, J.L. Zhang, Z.J. Liu, X. Xue, G.W. Wang, Q.F. Kang, Int. J. Miner. Metall. Mater. 24 (2017) 991-998. 